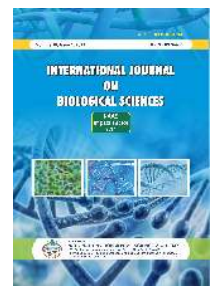

\title{
GEOSPATIAL TECHNIQUES APPROACH FOR LANDUSE AND LANDCOVER CHANGE ANALYSIS IN BALTANA OF ZIRAKPUR, PUNJAB AND PART OF SECTOR-19, PANCHKULA CITY, HARYANA
}

\author{
Anup Kumar ${ }^{1 *}$, Shivani ${ }^{2}$ and V.S. Arya ${ }^{3}$ \\ ${ }^{1}$ Front Office-HARSAC, Sector-2, Panchkula, Haryana \\ ${ }^{2}$ Govt. ITI, Sector-14, Panchkula, Haryana \\ ${ }^{3}$ Haryana Space Applications Centre (HARSAC), CCS HAU Campus, Hisar, Haryana
}

\section{Research Paper}

Received: 06.07.2020

Revised: 14.07.2020

Accepted: 28.07.2020

ABSTRACT

\begin{abstract}
In urban area information on landuse and land cover is important for monitoring, planning and management land resources. Remote sensing satellite data and Geographical Information System (GIS) are vital tools in mapping of land use and land cover in urban areas because of availability of historical high resolution satellite data. In the present study land use and land cover change analysis have been done in Baltana area of Zirakpur of Punjab and part of Sector-19, Panchkula city, Haryana. The study area is located between the latitudes $30^{\circ} 40^{\prime} 50.62^{\prime \prime} \mathrm{N}$ to $30^{\circ} 40^{\prime} 6.91^{\prime \prime} \mathrm{N}$ and longitudes $76^{\circ} 49^{\prime} 18.18$ ”E to 76.50'5.61”'E. The study area covers an area of 96.49 Hect. Google earth satellite data for the years 2002 and 2018 have been used in the study for change analysis in land use and land cover. The study shows that during 2002 to 2018 built-up area increased 29.57 Hect., agriculture land increased 2.92 Hect., agriculture plantation area increased 1.48 Hect., park area increased 0.54 Hect, road area increased 7.53 Hect,, vacant land area decreased 41.30 Hect and drainage area decreased 0.74 Hect. This study is highly useful for planning and management of land use and land cover in the study area.
\end{abstract}

Keywords: Landuse, landcover, change analysis, satellite data, Baltana, Panchkula.

\section{INTRODUCTION}

In the present fast developmental era availability of latest information about natural and cultural resources is become important for better planning and management. Remote sensing satellite data are highly useful for mapping of latest status of natural and cultural resources. Geographical Information System (GIS) provides a better presentation of data in spatial form. For mapping of landuse and landcover and change analysis remote sensing satellite data and GIS are very important tools. Availability of historical satellite data and presentation in GIS makes the interpreted data a meaningful source for planning and management land resources. Anchan et al. (2018), Basha et al. (2018), Bazgeer et al. (2008), Bello et al. (2014), Borsah et al.
(2018), Kleemann et al. (2017), Sarkar (2018), Muke and Haile (2018), Prakasam (2010), Ramamoorthy et al. (2016), Setiawan and Yoshino (2012), Vidhya and Thomas (2018) have done good work on mapping of land use and land cover using satellite data and GIS.

\section{STUDY AREA}

Baltanaarea of Zirakpur of Punjab and part of Sector-19, Panchkula city have been selected for the landuse and land cover change analysis. The study area is located between the latitudes $30^{\circ} 40^{\prime} 50.62^{\prime \prime} \mathrm{N}$ to $30^{\circ} 40^{\prime} 6.91^{\prime}$ ' $\mathrm{N}$ and longitudes $76^{\circ} 49^{\prime} 18.18$ ”'E to $76.50 ' 5.61$ ” E. The study area coversan area of96.49Hect. (Fig 1).

*Corresponding author: anup0106@yahoo.com 


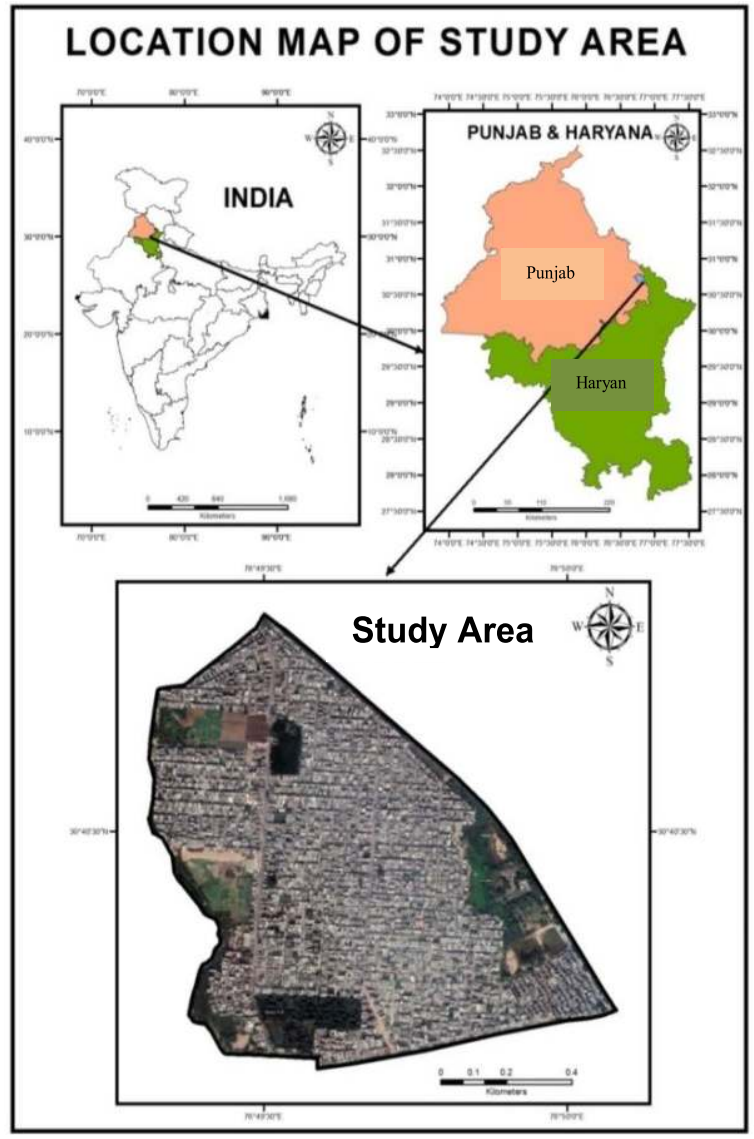

Fig.1: Location map of study area.

\section{OBJECTIVE}

The main objective was to study land use / land cover changes in the study area.

\section{MATERIALS USED AND METHODOLOGY}

Satellite data for the years 2002 and 2018 have been downloaded from Google Earth. ArcGIS 10.4 softwarehas been used for data georeferencing, interpretation and presentation. Both dates satellite data have been interpreted for land use and land cover classes. At selected locations field visit was done to check the interpreted land use and land cover classes. Final land use and land cover maps have been prepared for the years 2002 and 2018. Area of each land use and land cover classes of 2002 and 2018 has been calculated and interpreted the results.

\section{RESULTS AND DISCUSSION}

Landuse (LU) and land cover (LC) change analysis during the years 2002 to 20018 in the study area are given below:

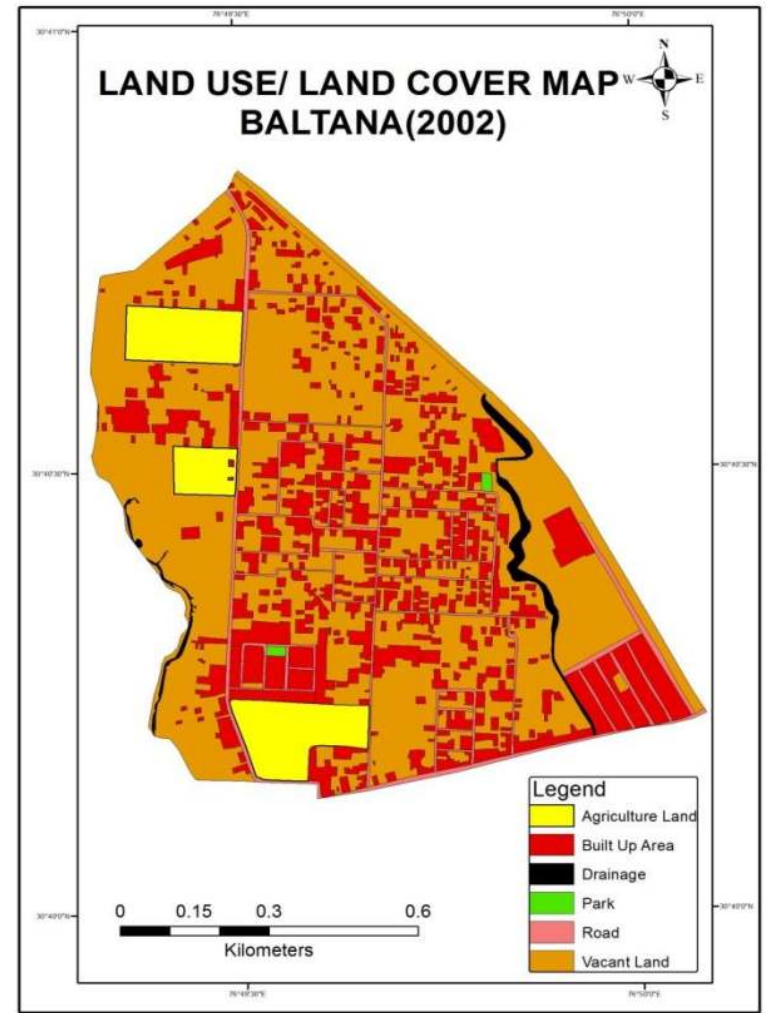

Fig.2: Land use/land cover map (2002).

\section{i. Built-up Land}

In the study area built-up land covers an area of 24.59 Hect. in 2002 and 54.16 Hect. in 2018. The built-up land has increased 29.57 Hect during 2002 to 2018 (Fig.2,Fig.3 and Table1).

\section{ii. Agriculture Land}

Agriculture land covers an area of 7.13 Hect.in 2002 and 10.05 Hect. in 2018. Agriculture land has increased 2.92 Hect. during 2002 to 2018 (Fig.2,Fig.3 and Table1).

\section{iii. Agriculture Plantation}

Agriculture plantation is a form of commercial farming where crops are grown for profits. In the year 2002 there was no agriculture plantation while in the year 2018 agriculture plantation was in 1.48 Hect. Agriculture plantation area increased 1.48 Hect. in 2018 (Fig.2,Fig.3 and Table1).

\section{iv. Drainage}

In the study area in 2002 drainage covered an area of 1.38 Hect. and0.64 Hect in 2018. Drainage area decreased 0.74 Hect during 2002 to 2018 (Fig.2,Fig.3 and Table1). 
Table1: Land use/ land cover classes and area (2002 and 2018).

\begin{tabular}{|l|c|c|c|}
\hline $\begin{array}{l}\text { Land use / Land } \\
\text { cover Classes }\end{array}$ & $\begin{array}{c}\text { Area (Hect) } \\
\text { in 2002 }\end{array}$ & $\begin{array}{c}\text { Area (Hect) } \\
\text { in 2018 }\end{array}$ & $\begin{array}{c}\text { Change in } \\
\text { Area (Hect) } \\
\text { (2002-2018) }\end{array}$ \\
\hline Builtup Land & 24.59 & 54.16 & +29.57 \\
\hline Agriculture Land & 7.13 & 10.05 & +2.92 \\
\hline Agriculture Plantation & 0 & 1.48 & +1.48 \\
\hline Park & 0.16 & 0.70 & +0.54 \\
\hline Road & 5.14 & 12.67 & 7.53 \\
\hline Drainage & 1.38 & 0.64 & -0.74 \\
\hline Vacant Land & 58.09 & 16.79 & -41.3 \\
\hline Total & $\mathbf{9 6 . 4 9}$ & $\mathbf{9 6 . 4 9}$ & \\
\hline
\end{tabular}

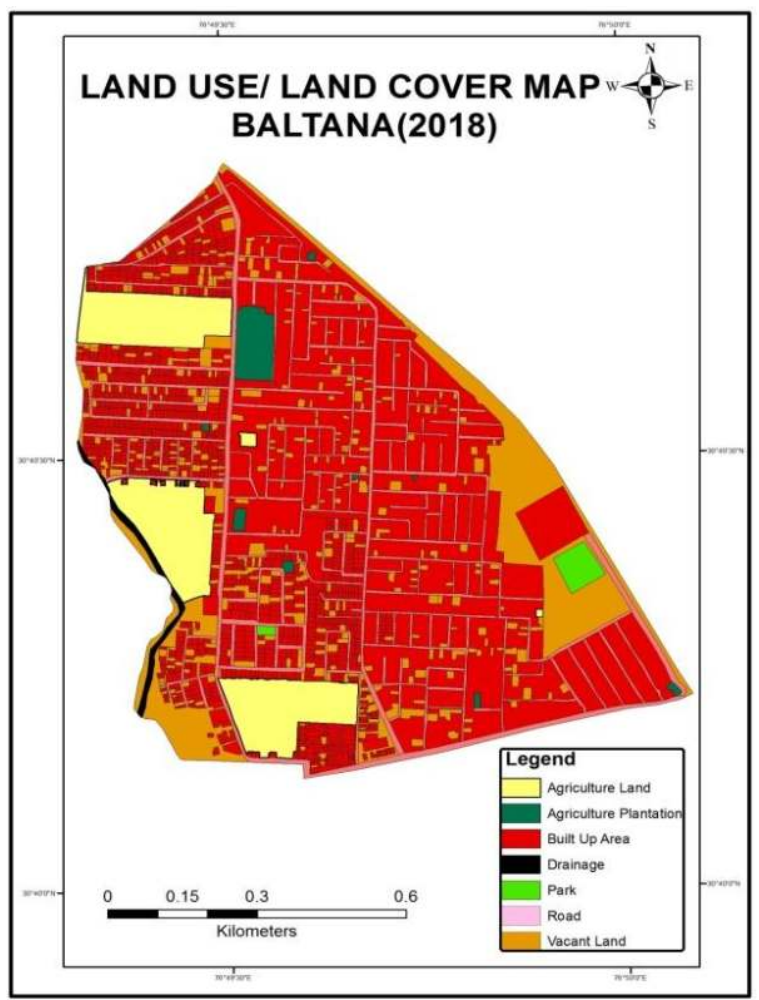

Fig.3: Land use/land cover map (2018).

\section{v. Vacant Land}

Vacant land was 58.09 Hect. in 2002 and 16.79 Hect. in 2018. Vacant land decreased 41.3 Hect during 2002 to 2018 (Fig.2,Fig.3 and Table1).

vi. Park

In the study area, park covered an area 0.16 Hect.in 2002 and 0.70 Hect.in 2018. Park area increased 0.54 Hect during 2002 to 2018 (Fig.2,Fig.3 and Table1).

\section{vii. Road}

Road covered an area of 5.14Hect. in 2002 and 12.67 Hect. in 2018. Road area increased 7.53 Hect during 2002 to 2018 (Fig.2,Fig.3 and Table1).

\section{CONCLUSIONS}

The study shows that during 2002 to 2018 built-up area increased 29.57 Hect., agriculture land increased 2.92 Hect., agriculture plantation area increased 1.48 Hect., park area increased 0.54 Hect, road area increased 7.53 Hect, vacant land area decreased 41.30 Hect and drainage area decreased 0.74 Hect. This study is highly useful for planning and management of land use and land cover in the study area.

\section{ACKNOWLEDGEMENTS}

Authors duly acknowledge the Google Earth for using their satellite data in the present study.

\section{REFERENCES}

1. Anchan, Sanjith S., Shetty Ateeth, Bhat, $\mathbf{H}$. Gangadhara and Chadaga, Mohandas (2018). Land use and land cover change detection through spatial approach: A case study of Mangaluru Taluk, Karnataka, Journal of Geomatics, 12 (2):167-173.

2. Basha, Imran, U., Suresh, U., Raju, G.Sudarsana, Rajasekhar,M., Veeraswamy.G., and Balaji,E. (2018).Landuse and land cover analysis using remote sensing and GIS: a case study in Somavathi river, Anantapur district, Andhra Pradesh, India, Nature Environment and Pollution Technology, An International Quarterly Scientific Journal,17(3):1029-1033. 
3. Bazgeer, S., Sharma,P.K., Mahey,R.K., Hundal, S.S. and Sood,A. (2008).Assessment of land use changes using remote sensing and GIS and their implications on climatic variability for Balachaur watershed in Punjab, India, Desert, 12:139-147.

4. Bello, Mohammed Nanoh, Abbas, Idowu Innocent and Akpu, Benedine (2014).Analysis of land use-land cover changes in Zuru and its environment of KebbiState,Nigeria using remote sensing and Geographical Information System Technology, Journal of Geography and Earth Sciences, 2 (1):113-126.

5. Borsah, A.Aidoo, Boah,E.Annan and Adu, A.Ohene (2018). Remote sensing and GIS assisted approach for land cover change detection with respect to elevation: a case study in Tarkwa,Western region of Ghana, The International Journal of Engineering and Sciences,7 (10 verI):61-67.

6. Kleemann, Janina, Baysal, Gulendam, Bulley,Henry,N.N. and Furst, Christine (2017). Assessing driving forces of land use and land cover change by a mixed-method approach in north-eastern Ghana, West Africa, Journal of Environmenatl Management,196:411-442.

7. Sarkar,Amit (2018).Accuracy assessment and analysis of land use land cover change using geoinformatics technique in Raniganj Coalfield Area, India, International Journal of Environmental Sciences \& Natural Resources, 11(1):25-34.
8. Muke, Mathewos and Haile, Bewuketu (2018).Land use/cover change analysis using remote sensing techniques in the landscape of Majang Zone of Gambella Region, Ethiopia, African Journal of Environmental Science and Technology, 12 (4):141-149.

9. Prakasam,C. (2010). Land use and land cover change detection through remote sensing approach: a case study of Kodaikanaltaluk, Tamil nadu, International Journal of Geomatics and Geosciences,1(2):150-158.

10. Ramamoorthy, P., Sundararaman,S. and Raju,S. (2016). Landuse and land cover change detection using remote sensing and GIS,a case study of Nandhiyar sub basin,Tamil Nadu, India, International Journal of Science \& Engineering, 2 (7):213-216.

11. Setiawan,Yudi and Yoshino,Kumihiko (2012). Change detection in landuse and land cover dynamics at a regional scale from MODIS time series imagery, ISPRS Annals of the Photogrammetry,Remote Sensing and spatial Information Sciences, XXII ISPRS Congress, 25 August-01 September 2012, Melbourne, Australia, 1-7:243-248.

12. Vidhya Lakshmi,S. and Thomas,S. (2018).Maping of land use and land cover changes in Chennai using GIS and remote sensing, International Journal of Pure and Applied Mathematics, 119 (17):11-21. 